\title{
HUBUNGAN ANTARA PERTUMBUHAN WAJIB PAJAK DAN PENERIMAAN PAJAK DI KANTOR PELAYANAN PAJAK (KPP) PRATAMA MATARAM BARAT
}

\author{
I Dewa Ketut Yudha Senopati \\ Fakultas Ekonomi dan Bisnis Universitas Mataram \\ dewayudha1229@gmail.com \\ Nisa Fitriani \\ Fakultas Ekonomi dan Bisnis Universitas Mataram \\ nisafitriani205@gmail.com
}

\begin{abstract}
Pajak merupakan sumber pendapatan negara yang sampai sekarang menjadi bagian yang paling utama bagi kesejahteraan masyarakat di Indonesia. Pajak merupakan kontribusi yang diberikan oleh wajib pajak kepada negara yang berdasarkan undang-undang bersifat wajib dan memaksa tanpa ada kontraprestasi (imbalan) secara langsung yang diterima oleh wajib pajak dengan tujuan untuk pembangunan sarana dan prasarana demi kemakmuran rakyat. Pajak berdasarkan Undang-Undang merupakan pungutan wajib yang dibayar rakyat untuk negara dan akan digunakan untuk kepentingan pemerintah dan masyarakat umum. Pajak merupakan sumber penerimaan terbesar bagi pemerintah Indonesia memegang peranan terpenting dalam perekonomian dan bersifat strategis. (Subagiyo et.al,2014). Peningkatan jumlah wajib pajak dan penerimaan pajak (PPh, PPN dan PPnBM) meningkat atau menurun dipengaruhi oleh kepatuhan wajib pajak dalam melaporkan pajak yang menjadi kewajibannya kepada Negara. Kepatuhan wajib pajak mempunyai hubungan positif dengan penerimaan pajak. Apabila wajib pajak patuh membayar pajak maka pertumbuhan wajib pajak akan meningkat begitu juga dengan penerimaan pajak. Jumlah wajib pajak orang pribadi dan jumlah perkembangan wajib pajak meningkat dari tahun ke tahun yaitu 2015-2020. Jumlah wajib pajak badan dari tahun ke tahun meningkat akan tetapi jumlah perkembangan wajib pajak tidak signifikan yaitu kadang naik dan kadang turun. Pertumbuhan Wajib Pajak Orang Pribadi dan Badan tiap tahunnya meningkat, begitu juga dengan Penerimaan PPh, PPN dan PPnBM meningkat karena pertumbuhan wajib pajak memiliki hubungan yang positif terhadap penerimaan pajak, maka dari itu naik turunnya penerimaan tergantung dari kepatuhan wajib pajak dan pertumbuhan wajib pajaknya. Kepatuhan wajib pajak mempunyai hubungan positif dengan penerimaan pajak. Kata Kunci : Wajib Pajak, Penerimaan Pajak
\end{abstract}

\section{PENDAHULUAN}

Pajak berdasarkan Undang-Undang merupakan pungutan wajib yang dibayar rakyat untuk negara dan akan digunakan untuk kepentingan masyarakat umum. Pajak merupakan sumber penerimaan terbesar bagi pemerintah Indonesia memegang peranan terpenting dalam perekonomian dan bersifat strategis dan merupakan salah satu bentuk partisipasi masyarakat dalam mewujudkan serta mendukung dan meningkatkan kesejahteraan negara. Pajak merupakan penerimaan negara terbesar yang dipergunakan untuk membiayai penyelenggaraan pemerintah, pelayanan umum dan pembangunan masional. (Subagiyo et.al,2014).

Pajak dianggap sebagai sumber penerimaan negara terbesar. Kurang lebih 2/3 penerimaan Negara saat ini bersumber dari pajak. Dominasi pajak sebagai sumber penerimaan merupakan satu hal yang sangat wajar, terlebih ketika sumber daya alam, khususnya minyak bumi tidak bisa lagi diandalkan. Penerimaan dari sumber daya alam 
mempunyai umur yang relatif terbatas, suatu saat akan habis dan tidak bisa diperbaharui. Hal ini berbeda dengan pajak, sumber penerimaan ini mempunyai umur tidak terbatas, terlebih dengan semakin bertambahnya jumlah penduduk (Widayati dan Nurlis, 2010).

Kepatuhan wajib pajak dalam membayar pajak merupakan hal yang sangat penting dalam peningkatan penerimaan pajak. Karena pertumbuhan Wajib Pajak sangat berpengaruh terhadap penerimaan pajak. Dengan demikian pengkajian terhadap faktor-faktor yang dapat mempengaruhi kepatuhan wajib pajak sangat perlu mendapatkan perhatian. Hal ini terbukti dengan adanya tunggakan pajak yang terjadi setiap tahun.

Kepatuhan wajib pajak merupakan suatu tindakan patuh dan sadar terhadap ketertiban pembayaran dan pelaporan kewajiban perpajakan masa dan tahunan dari wajib pajak yang berbentuk sekumpulan orang dan/ atau modal yang merupakan usaha sesuai dengan ketentuan perpajakan yang berlaku.

Menurut Wahyu, Maslichah dan Junaidi (2019: 32) pertumbuhan wajib pajak adalah nilai terhadap banyaknya wajib pajak yang terdaftar berstatus secara aktif, untuk kewajiban perpajakannya di setiap tahunnya. Wajib pajak adalah orang pribadi atau badan meliputi pembayar pajak, pemotong pajak, dan pemungut pajak, yang mempunyai hak dan kewajiban perpajakan sesuai dengan ketentuan perundangundangan perpajakan.

Kenyatannya, kepatuhan dan tingkat pertumbuhan wajib pajak di Indonesia masih rendah dikarenakan kurangnya pemahaman tentang pajak dari wajib pajak itu sendiri. Kepatuhan pajak dapat dipengaruhi oleh faktor yang sangat bervariasi. Faktor tersebut dibedakan menjadi faktor internal dan faktor eksternal. Faktor internal adalah meliputi pengetahuan terhadap peraturan perpajakan kesadaran dan motivasi wajib pajak. Singkatnya perilaku yang berkaitan dengan pribadi seorang indvidu sebagai wajib pajak. Pengetahuan tentang perpajakan merupakan faktor yang dapat mempengaruhi karena berkaitan dengan perilaku patuh. Faktor eksternal adalah kurangnya pelayanan, sarana dan prasarana dan sosialisasi perpajakan. Zaman sekarang tidak jarang ditemukan petugas-petugas pelayanan administrasi yang lalai dalam menjalankan tugasnya. Jangankan petugas, terkadang sarana yang menjadi wadah pelaporan pajakpun juga bisa bermasalah. Sebenarnya faktor internal dan eksternal sangat berpengaruh satu sama lain.Tidak adanya sosialisasi perpajakan menimbulkan ketidaktahuan mengenai pengetahuan perpajakan, hasil akhirnya tidak patuh. Kurangnya pelayanan sarana dan prasarana perpajakan yang memadai juga berpengaruh dalam rendahnya motivasi untuk melapor pajak. Semakin tinggi tingkat kepatuhan wajib pajak, maka semakin tinggi keberhasilan penerimaan pajak. Dengan demikian, target pajak dapat tercapai. Sebaiknya pemerintah menganggap serius faktor-faktor yang mempengaruhi tingkat kepatuhan pajak. Faktor internal dan eksternal sangat berpengaruhi. Jangan hanya bisa menerapkan penerimaan target pajak yang tinggi karena percuma. Tidak semua orang memahami betul tentang perpajakan. Oleh karena itu langkah sosialisasi dari pemerintah, penyediaan sarana dan prasarana pajak dan pelayanan yang baik secara sendirinya nanti akan mengedukasi masyarakat agar masyarakat tidak mengalami kesulitan dalam memenuhi kewajiban perpajakannya. Selain itu penegakan hukum yang ketat berupa sanksi perpajakan apabila tidak memenuhi kewajibannya adalah hal yg penting. Dianggap penting karena selain fakta Indonesia adalah negara hukum dan pajak bersifat memaksa, hal ini dilakukan juga demi keadilan. Tidak adil rasanya wajib pajak dengan sukarela membayar pajak, tetapi ada juga wajib pajak yang tidak membayar pajak. Padahal sama-sama tinggal dan menggunakan fasilitas negara. Selain itu sanksi pajak bisa dijadikan jaminan bahwa peraturan perpajakan dipatuhi oleh wajib pajak. Singkatnya sanksi pajak adalah 'alat' pencegah agar wajib pajak tetap patuh terhadap 
peraturan perpajakan. Sanksi perpajakan dapat diberikan kepada siapa saja jika lalai dalam menjalankan kewajiban perpajakannya.

Dalam upaya pemenuhan kewajiban perpajakan secara sukarela untuk meningkatkan jumlah pertumbuhan wajib pajak serta mendorong kontribusi penerimaan kas Negara, Sebagai wajib pajak, kepatuhan dalam melaksanakan kewajiban perpajakan merupakan hal yang sangat penting untuk dilakukan. Upaya peningkatan kesadaran akan kewajiban perpajakan harus dianggap sebagai prioritas. Kebijakan pemerintah menerapkan sistem self assesement, dimana wajib pajak diberi tanggung jawab sepenuhnya untuk mengurus perpajakannya mulai dari daftar, hitung, bayar, lapor. Karena, apabila wajib pajak patuh melaksanakan kewajibannya membayar pajak, maka pertumbuhan wajib pajak akan meningkat dan penerimaan pajak juga akan meningkat.

Dengan meningkatnya pemenuhan kewajiban wajib pajak maka pertumbuhan wajib pajak akan meningkat dan penerimaan pajak juga akan meningkat. Hubungan antara pertumbuhan wajib pajak dan penerimaan pajak sangat kuat, karena penerimaan pajak meningkat ataupun menurun tergantung pertumbuhan wajib pajak dan kepatuhan wajib pajak, Jika pertumbuhan wajib pajak meningkat otomatis penerimaan pajak akan semakin banyak, begitu pula sebaliknya apabila pertumbuhan wajib pajak menurun maka penerimaan pajak juga akan menurun.

Berdasarkan latar belakang masalah yang telah diuraikan diatas maka inilah yang menjadi alasan penulis memilih judul "Hubungan antara Pertumbuhan Wajib Pajak Dan Penerimaan Pajak di KPP Pratama Mataram Barat".

\section{TUJUAN}

1. Mengetahui tentang Hubungan antara Pertumbuhan wajib pajak dan penerimaan pajak menurut klasifikasi pajak di KPP Pratama Mataram Barat dari tahun ke tahun.

\section{TELAAH LITERATUR DAN PENGEMBANGAN HIPOTESIS}

\section{Pengertian Pajak}

Adapun pengertian pajak secara umum menurut Undang-Undang Perpajakan dan bebrapa ahli ialah:

a. Menurut Undang-Undang Nomor 16 Tahun 2009 tentang "Ketentuan Umum dan Tata Cara Perpajakan". "Pajak adalah konstribusi wajib pajak kepada Negara yang terutang oleh orang pribadi atau badan yang bersifat memaksa berdasarkan Undang-Undang, dengan tidak mendapatkan imbalan secara langsung dan digunakan untuk keperluan Negara bagi sebesar-besarnya kemakmuran rakyat".

b. Menurut Mardiasmo (2011:1) "Pajak adalah iuran rakyat kepada kas Negara berdasarkan Undang-Undang (yang dapat dipaksakan) dengan tiada mendapat jasa timbal (kontraprestasi) yang langsung dapat ditujunjukkan dan yang digunakan untuk membayar pengeluaran umum".

c. Menurut Waluyo (2011:2) bahwa "Pajak adalah iuran wajib berupa uang atau barang yang dipungut oleh pengusaha berdasarkan norma-norma hukum, guna menutup biaya produksi barang-barang dan jasa-jasa kolektif dalam mencapai kesejahteraan umum".

d. Menurut P.J.A Andriani yang disampaikan oleh R. Santoso Brotodiharjo, S.H. (2011:2) "Pajak ialah iuran masyarakat kepada Negara (yang dipaksakan) yang terutang oleh yang wajib membayarnya menurut peraturan-peraturan umum (undang-undang) dengan tidak mendapat prestasi kembali yang langsung dapat 
ditunjuk dan yang gunanya adalah untuk membiayai pengeluaran-pengeluaran umum berhubung tugas Negara untuk menyelenggarakan pemerintahan".

Dari definisi tersebut, dapat disimpulkan bahwa pajak memiliki unsur-unsur Mardiasmo (2011:1) sebagai berikut:

1. Iuran wajib dari rakyat kepada Negara

Yang berhak melakukan pemungutan pajak hanyalah Negara, dan iuran yang dipungut tersebut berupa uang (bukan barang).

2. Berdasarkan Undang-undang

Pajak dipungut oleh Negara berdasarkan atau dengan kekuatan Undang-Undang beserta aturan pelaksanannya.

3. Tanpa jasa timbal atau kontraprestasi dari negara yang secara langsung dapat ditunjuk. Dalam pembayaran pajak tidak dapat ditunjukkan adanya kontraprestasi individual oleh pemerintah.

4. Digunakan untuk membiayai rumah tangga Negara, yakni pengeluaran-pengeluaran pemerintah yang bermanfaat bagi masyarakat luas.

\section{Fungsi pajak}

Ada 2 fungsi pajak menurut Mardiasmo (2011:1-2) ialah:

1. Fungsi Budgetair (Sebagai penerimaan Negara)

Pajak merupakan sumber dana bagi pemerintah untuk membiayai pengeluaranpengeluarannya.

2. Fungsi Regulerend (Mengatur)

Pajak sebagai alat untuk mengatur atau melaksanakan kebijaksanaan pemerintah dalam bidang social dan ekonomi, misalnya:

a. Pajak yang tinggi dikenakan terhadap minuman keras untuk mengurangi konsumsi minuman keras.

b. Pajak yang tinggi dikenakan terhadap barang-barang mewah untuk mengurangi gaya hidup konsumtif.

c. Tarif pajak untuk ekspor sebesar 0\% untuk mendorong ekspor produk Indonesia di pasaran dunia.

\section{Jenis-Jenis Pajak}

1. Jenis pajak menurut golongannya :

a. Pajak Langsung, yaitu pajak yang harus dipikul sendiri oleh wajib pajak dan tidak dapat dibebankan atau dilimpahkan kepada orang lain. Contoh : Pajak Penghasilan.

b. Pajak tidak langsung, yaitu pajak yang pada akhirnya dapat dibebankan atau dilimpahkan kepada orang lain.

Contoh : Pajak Pertambahan Nilai

2. Jenis pajak menurut sifatnya :

a. Pajak Subyektif, yaitu pajak yang berpangkal atau berdasarkan pada subyeknya,dalam arti memerhatikan keadaan diri Wajib Pajak.

Contoh : Pajak Penghasilan

b. Pajak Obyektif, yaitu pajak yang berpangkal pada objeknya, tanpa memerhatikan keadaan diri Wajib Pajak.

Contoh : Pajak Pertambahan Nilai dan Pajak Penjualan atas Barang Mewah.

3. Jenis pajak menurut lembaga pemungutannya :

a. Pajak Pusat, yaitu pajak yang dipungut oleh pemerintah pusat dan digunakan untuk membiayai rumah tangga Negara.

Contoh : Pajak Penghasilan, Pajak Pertambahan Nilai dan Pajak Penjualan atas

Barang Mewah, dan Bea Materai 
b. Pajak Daerah, yaitu pajak yang dipungut oleh pemerintah daerah dan digunakan untuk membiayai rumah tangga daerah.

Pajak Daerah terdiri atas :

1. Pajak Provinsi, contoh : Pajak Kendaraan Bermotor dan Pajak Bahan Bakar Kendaraan Bermotor.

2. Pajak Kabupaten/Kota, contoh : Pajak Hotel, Pajak Restoran, dan Pajak Hiburan.

\section{Tata Cara Pemungutan Pajak}

Pemungutan pajak dapat dilakukan berdasarkan 3 stelsel :

a. Stelsel nyata (Riel Stelsel)

Pengenaan pajak didasarkan pada objek (penghasilan yang nyata), sehingga pemungutan baru dapat dilakukan pada akhir tahun pajak, yaitu setelah penghasilan yang sesungguhnya diketahui. Stelsel nyata mempunyai kelebihan atau kebaikan dan kekurangan. Kebaikan stelsel ini adalah pajak yang dikenakan lebih realistis. Sedangkan kelemahannya adalah pajak baru dapat dikenakan pada akhir periode (setelah penghasilan riil diketahui).

b. Stelsel anggapan (Fictieve Stelsel)

Pengenaan pajak didasarkan pada suatu anggapan yang diatur oleh undangundang. Misalnya penghasilan suatu tahun dianggap sama dengan tahun sebelumnya, sehingga pada awal tahun pajak sudah dapat ditetapkan besarnya pajak yang terutang untuk tahun pajak berjalan. Kebaikan stelsel ini adalah pajak dapat dibayar selama tahun berjalan, tanpa harus menunggu pada akhir tahun. Sedangkan kelemahannya adalah pajak yang dibayar tidak berdasarkan pada keadaan yang sesungguhnya.

c. Stelsel Campuran

Stelsel ini nerupakan kombinasi antara stelsel nyata dengan stelsel tanggapan. Pada awal tahun, besarnya pajak dihitung berdasarkan suatu anggapan, kemudian pada akhir tahun besarnya pajak disesuaikan dengan keadaan yang sebenarnya. Bila besarnya pajak menurut kenyataan lebih besar dari pada pajak menurut anggapan, maka Wajib Pajak harus menambah. Sebaliknya, jika lebih kecil kelebihannya dapat diminta kembali.

\section{Syarat pemungutan pajak}

Agar pemungutan pajak tidak menimbulkan hambatan atau perlawanan, maka pemungutan pajak harus memenuhi syarat sebagai berikut:

1. Pemungutan pajak harus adil (Syarat Keadilan)

Sesuai dengan tujuan hukum, yakni mencapai keadilan, undang-undang dan pelaksanaan pemungutan harus adil. Adil dalam perundang-undangan diantaranya mengenakan pajak secara umum dan merata, serta disesuaikan dengan kemampuan masing-masing. Sedang adil dalam pelaksanannya yakni dengan memberikan hak bagi Wajib Pajak untuk mengajukan keberatan, penundaan dalam pembayaran dan mengajukan banding kepada Majelis Pertimbangan Pajak.

2. Pemungutan pajak harus berdasarkan undang-undang (Syarat Yuridis)

Di Indonesia, pajak diatur dalam UUD 1945 pasal 23 ayat 2. Hal ini memberikan jaminan hukum untuk menyatakan keadilan, baik bagi negara maupun warganya.

3. Tidak mengganggu perekonomian (Syarat Ekonomis)

Pemungutan tidak boleh mengganggu kelancaran kegiatan produksi maupun perdagangan, sehingga tidak menimbulkan kelesuan perekonomian masyarakat.

4. Pemungutan pajak harus efisien (Syarat Finansiil)

Sesuai fungsi budgetair biaya pemungutan pajak harus dapat ditekan sehingga lebih rendah dari hasil pemungutannya. 


\section{Sistem pemungutan pajak harus sederhana}

Sistem pemungutan yang sederhana akan memudahkan dan mendorong masyarakat dalam memenuhi kewajiban perpajakannya. Syarat ini telah dipenuhi oleh undang-undang perpajakan yang baru.

\section{Pengertian Pertumbuhan Wajib Pajak}

Menurut Wahyu, Maslichah dan Junaidi (2019: 32) pertumbuhan wajib pajak adalah nilai terhadap banyaknya wajib pajak yang terdaftar berstatus secara aktif, untuk kewajiban perpajakannya di setiap tahunnya. Wajib pajak adalah orang pribadi atau badan meliputi pembayar pajak, pemotong pajak, dan pemungut pajak, yang mempunyai hak dan kewajiban perpajakan sesuai dengan ketentuan perundangundangan perpajakan.

Adapun menurut Laporan Kinerja Direktorat Jenderal Pajak (2017), untuk strategi peningkatan rasio pertumbuhan wajib pajak badan dan orang pribadi non karyawan yang melakukan pembayaran adalah sebagai berikut: melakukan pengawasan pembayaran masa sebagaimana dalam peraturan Surat Edaran Direktur Jenderal Pajak Nomor SE-27/PJ/2012, tentang Pengawasan Pembayaran Masa, dengan langkah-langkah sebagai berikut :

a. Memanfaatkan data internal (Aplikasi Portal DJP dan Approweb) dan data eksternal (data yang berasal dari pelaksanaan Peraturan Pemerintah Nomor PP 31 Tahun 2012, tentang Pemberian dan Penghimpunan Data dan Informasi).

b. Melakukan pengawasan kepatuhan pembayaran wajib pajak dengan kontribusi penerimaan sebesar $90 \%$ dari penerimaan nasional di Dashboard Pengawasan Wajib Pajak Besar yang tersedia di menu Dashboard Penerimaan.

\section{Penerimaan Pajak}

Menurut Mardiasmo (2016: 342) penerimaan pajak merupakan sumber penerimaan yang dapat diperoleh secara terus-menerus, dan dapat dikembangkan secara optimal sesuai kebutuhan pemerintah serta kondisi masyarakat. Penerimaan pajak merupakan sumber pembiayaan negara yang dominan baik untuk belanja rutin maupun pembangunan. Kesimpulannya bahwa yang diterima di kas negara tersebut akan dipergunakan untuk pengeluaran pemerintah untuk sebesar-besarnya pengeluaran rakyat, sebagaimana maksud dari tujuan negara yang disepakati oleh pendiri awal negara ini yaitu menyejahterakan rakyat, menciptakan kemakmuran yang berasaskan keadilan sosial.

Menurut Undang-undang No. 36 Tahun 2008, pengertian penerimaan pajak penghasilan merupakan penerimaan yang bersumber dari angsuran pajak dalam tahun berjalan yang telah dibayar oleh wajib pajak dan dilaksanakan setiap bulan. Adapun faktor- faktor yang mempengaruhi sumber penerimaan pajak sebagai berikut:

a. Kejelasan, kepastian dan kesederhanaan peraturan perundang-undangan perpajakan Mekanisme perpajakan yang mudah dipahami dan sederhana, pelaksanaan undang- undang yang jelas dan tegas tidak akan menimbulkan salah interpretasi, dampaknya akan menimbulkan motivasi pemenuhan kewajiban perpajakan sebagaimana mestinya. Dengan demikian hal ini akan memperlancar penerimaan negara dari sektor pajak. Kesadaran dan kepatuhan pemenuhan kewajiban perpajakan akan terbentuk dengan peraturan yang tidak berbelit-belit. Prosedur yang tidak rumit dengan formulir yang mudah dimengerti pengisiannya oleh wajib pajak.

b. Kebijakan pemerintah

Pencapaian di bidang sosial dan ekonomi yang merupakan sasaran utama sumber penerimaan pajak harus didukung oleh kebijakan pemerintah, dalam mengimplementasikan undang-undang perpajakan tersebut. Kebijakan dalam hal ini 
adalah hal-hal tertentu dalam perpajakan yang tidak dijelaskan secara rinci dalam undang-undang. Pemerintah diberikan asas Freies Ermessen (kebebasan bertindak) dalam bentuk tertulis yang berupa peraturan kebijaksanaan, berupa peraturan lain yang menjelaskan petunjuk pelaksanaan peraturan perundang-undangan.

c. Sistem administrasi

Merujuk pada kualitas pelayanan, sistem administrasi merupakan prioritas utama bagi pemerintah agar fungsinya berjalan secara efektif dan efisien. Sistem administrasi memegang peran penting, maka sistem tersebut diharapkan penekannya berupa kesederhanaan prosedur. Kerumitan sistem akan membuat wajib pajak semakin enggan membayar pajak.

d. Pelayanan

Pemberian pelayanan yang prima kepada masyarakat dalam hal ini wajib pajak akan berdampak pada optimalisasi penerimaan pajak. Pemerintah harus peka terhadap kebutuhan wajib pajak yang memiliki kewajiban membayar pajak, kebutuhan tersebut berupa pelayanan akan informasi mulai dari sistem pembayaran, hal tersebut dapat diperoleh dari pelayanan aparat perpajakan yang disediakan oleh pemerintah.

e. Kesadaran dan pemahaman warga negara

Sosialisasi kepada wajib pajak merupakan salah satu wujud dari pelayanan yang diberikan kepada wajib pajak, ada banyak faktor yang menghambat wajib pajak untuk memenuhi kewajibannya salah satunya adalah tingkat kesadaran yang timbul oleh ketidakpahaman. Kesadaran dapat ditumbuhkan dengan meningkatkan pemahaman wajib pajak itu sendiri tentang kewajibannya kepada negara, hal tersebut dapat di antisipasi sosialisasi sebagai langkah yang paling sederhana. Maka secara umum akan makin mudah bagi wajib pajak untuk patuh kepada peraturan perpajakan.

f. Kualitas petugas pajak (intelektual, keterampilan, integritas, moral tinggi)

Berjalannya sistem tentu saja didukung oleh yang menjalankan, dalam hal ini yang menjalankan sistem perpajakan adalah aparat pajak/petugas pajak. Petugas pajak memiliki reputasi yang baik sepanjang yang menyangkut kecakapan teknis, efisien dan efektif dalam hal kecepatan, tepat dan keputusan yang adil. Petugas pajak yang berhubungan dengan masyarakat pembayar pajak harus memiliki intelektualitas tinggi, terlatih baik, digaji baik dan bermoral tinggi.

\section{Wajib Pajak}

Menurut Resmi (2016: 138), bahwa wajib pajak wajib pajak dengan peredaran bruto tertentu dalam PPh bersifat final $1 \%$ sebagai berikut:

a. Wajib pajak orang pribadi dan badan kecuali bentuk usaha tetap.

b. Wajib pajak pada nomor 1 menerima penghasilan dari usaha tidak termasuk penghasilan jasa sehubungan dengan pekerjaan bebas, dengan peredaran bruto tidak melebihi Rp. 4.800.000.000 untuk semua cabang dalam 1 tahun pajak.

Jasa sehubungan dengan pekerjaan bebas, meliputi hal-hal berikut yaitu tenaga ahli yang melakukan pekerjaan bebas seperti pengacara, akuntan, arsitek, dokter, konsultan, notaris, penilai, aktuaris, pemain musik, pembawa acara, penyanyi, pelawak, bintang film, bintang sinetron, bintang iklan, sutradara, kru film, foto model, peragawan/peragawati, pemain drama, penari, olahragawan, penasihat, pengajar, pelatih, penceramah, penyuluh, moderator, pengarang, peneliti, penerjemah, agen iklan, pengawas atau pengelola proyek, perantara, petugas penjaja barang dagangan, agen asuransi, distributor perusahaan pemasaran berjenjang (multi level marketing) atau penjualan langsung (direct selling) dan kegiatan sejenis lainnya.

Berikut tidak termasuk wajib pajak dalam PPh bersifat final 1\%, meliputi: 
a. Wajib pajak orang pribadi yang melakukan kegiatan usaha perdagangan atau jasa yang dalam usahanya:

1) Menggunakan sarana atau prasarana yang dapat dibongkar pasang, baik yang menetap maupun tidak menetap.

2) Menggunakan sebagian atau seluruh tempat untuk kepentingan umum yang tidak diperuntukkan bagi tempat usaha atau berjualan.

b. Wajib pajak badan, meliputi:

1) Belum beroperasi secara komersial.

2) Dalam jangka waktu 1 tahun setelah beroperasi secara komersial memperoleh peredaran bruto melebihi Rp. 4.800.000.000.

Laju pertumbuhan wajib pajak terdaftar menunjukkan kemampuan DJP dalam meningkatkan jumlah wajib pajak terdaftar dari periode ke periode berikutnya. Menurut Pekei (2016: 75) untuk mengetahui laju pertumbuhan digunakan rumus sebagai berikut:

$$
\Delta X=\frac{X_{t}-X_{(t-1)}}{X_{(t-1)}} \times 100 \%
$$

Keterangan:

$\Delta \mathrm{X}=$ rasio pertumbuhan wajib pajak

$\mathrm{Xt}=$ jumlah wajib pajak setiap bulan rutin

$X(t-1)=$ jumlah wajib pajak pada bulan sebelumnya

Skala pengukuran laju pertumbuhan didasarkan pada kriteria yang disusun dalam tabel berikut:

Tabel 1. Kriteria laju pertumbuhan

\begin{tabular}{l|l}
\hline \multicolumn{1}{c|}{$\begin{array}{c}\text { Presentase laju } \\
\text { pertumbuhan }\end{array}$} & \multicolumn{1}{c}{ Kriteria } \\
\hline $85 \%-100 \%$ & Sangat berhasil \\
\hline $70 \%-85 \%$ & Berhasil \\
\hline $55 \%-70 \%$ & Cukup berhasil \\
\hline $30 \%-55 \%$ & Kurang berhasil \\
\hline Kurang dari 30\% & Tidak berhasil \\
\hline Sumber: Pekei, 2006. Hal 75 &
\end{tabular}

\section{PENGUMPULAN DAN ALAT ANALISIS DATA}

Data yang digunakan dalam penulisan Artikel ini adalah data sekunder yang bersumber dari Kantor Pelayanan Pajak Pratama Mataram Barat.

1. Rumus yang digunakan untuk menghitung perkembangan wajib pajak yaitu:

$$
\text { Perkembangan WP }=\frac{\left(\sum \mathrm{WP} \text { thn sekarang }-\sum \mathrm{WP} \text { tahun sebelumnya }\right)}{\sum \mathrm{WP} \text { thn sebelumnya }} \times 100 \%
$$


2. Rumus yang digunakan untuk menghitung pertumbuhan penerimaan adalah

Pertumbuhan Penerimaan

$$
\begin{aligned}
& =\frac{\sum \text { Penerimaan thn ini }-\sum \text { Penerimaan thn sebelumnya }}{\sum \text { Penerimaan thn sebelumnya }} \\
& \times 100 \%
\end{aligned}
$$

HASIL PENELITIAN DAN PEMBAHASAN

\section{Perkembangan Wajib Pajak}

Tabel 2. Wajib Pajak Orang Pribadi

\begin{tabular}{l|l|l}
\hline \multicolumn{1}{c|}{ Tahun } & Wajib Pajak (Orang Pribadi) & \multicolumn{1}{c}{ Perkembangan Wajib Pajak (\%) } \\
\hline 2015 & 80406 & - \\
\hline 2016 & 85771 & 6.67 \\
\hline 2017 & 90333 & 5.31 \\
\hline 2018 & 95220 & 5.40 \\
\hline 2019 & 99966 & 4.98 \\
\hline 2020 & 131312 & 31.35 \\
\hline JML & 53.74 \\
\hline Rata & 10.74 \\
\hline
\end{tabular}

Sumber: KPP Pratama Mataram Barat

Pada tabel diatas bisa dilihat bahwa jumlah wajib pajak orang pribadi dan jumlah perkembangan wajib pajak meningkat dari tahun ke tahun yaitu 2015-2020. Jumlah wajib pajak tertinggi yaitu pada tahun 2020 sebanyak 131.312 orang dengan jumlah perkembangan wajib pajak sebesar $31.35 \%$. Sedangkan jumlah wajib pajak terendah yaitu pada tahun 2015 sebanyak 80.406 orang dengan jumlah perkembangan wajib pajak sebesar tidak ada karena pada tabel diatas tidak tertera jumlah wajib pajak pada tahun sebelumnya.

Tabel 3. Wajib Pajak Badan

\begin{tabular}{l|l|l}
\hline \multicolumn{1}{c|}{ Tahun } & \multicolumn{1}{|c|}{ Wajib Pajak (Unit) } & \multicolumn{1}{c}{ Perkembangan Wajib Pajak (\%) } \\
\hline 2015 & 9662 & - \\
\hline 2016 & 10275 & 6.34 \\
\hline 2017 & 10913 & 6.20 \\
\hline 2018 & 11756 & 5.40 \\
\hline 2019 & 12433 & 4.98 \\
\hline 2020 & 13194 & 31.35 \\
\hline JML & 54.30 \\
\hline Rata & 10.86
\end{tabular}

Sumber: KPP Pratama Mataram Barat

Pada tabel diatas bisa dilihat bahwa jumlah wajib pajak badan dari tahun ke tahun meningkat akan tetapi jumlah perkembangan wajib pajak tidak menentu yaitu kadang mengalami kenaikan dan kadang menurun. Jumlah wajib pajak tertinggi yaitu pada tahun 2020 sebanyak 13.194 unit dengan jumlah perkembangan wajib pajak sebesar 31.35\%. Sedangkan jumlah wajib pajak terendah yaitu pada tahun 2015 sebanyak 9.662 unit dengan jumlah perkembangan wajib pajak sebesar tidak ada karena pada tabel diatas tidak tertera jumlah wajib pajak pada tahun sebelumnya.

$=(\underline{10275-9662}) \times 100 \%$ $\underline{9662}$

$=6.34 \%$ 
Perkembangan WP $=\frac{\left(\sum \mathrm{WP} \text { thn sekarang }-\sum \mathrm{WP} \text { tahun sebelumnya }\right)}{\sum \mathrm{WP} \text { thn sebelumnya }} \times 100 \%$

Perkembangan Penerimaan Pajak

Tabel 4. Penerimaan PPh, PPN dan PPnBM Wajib Pajak Orang Pribadi dan Badan

\begin{tabular}{|c|c|c|c|c|}
\hline \multirow{2}{*}{ Tahun } & \multirow{2}{*}{$\begin{array}{l}\text { Wajib Pajak } \\
\text { (Orang } \\
\text { Pribadi dan } \\
\text { Badan) }\end{array}$} & \multicolumn{2}{|c|}{$\begin{array}{c}\text { Penerimaan (Wajib Pajak Orang } \\
\text { Pribadi dan Badan) }\end{array}$} & \multirow{2}{*}{$\begin{array}{l}\text { Total penerimaan } \\
(\mathbf{R p})\end{array}$} \\
\hline & & $\begin{array}{l}\text { PPh } \\
\text { (Rp) }\end{array}$ & $\begin{array}{c}\text { PPN dan PPnBM } \\
\text { (Rp) }\end{array}$ & \\
\hline 2015 & 93.272 & 536.606 .425 .330 & 273.161 .678 .332 & 809.768 .103 .662 \\
\hline 2016 & 99.283 & 683.586 .604 .237 & 314.141 .019 .679 & 997.727 .623 .952 \\
\hline 2017 & 104.523 & 733.276 .916 .251 & 348.829 .567 .307 & 1.082 .106 .483 .558 \\
\hline 2018 & 110.282 & 761.600 .894 .107 & 341.275 .800 .026 & 1.102 .876 .694 .133 \\
\hline 2019 & 115.718 & 679.803 .788 .133 & 343.418 .217 .117 & 1.023 .222 .005 .250 \\
\hline 2020 & 127.289 & 747.784 .166 .946 & 345.560 .634 .208 & 1.093 .344 .801 .154 \\
\hline \multicolumn{2}{|l|}{$\mathrm{JML}$} & 4.142 .658 .795 .040 & 1.966 .386 .916 .669 & 6.109 .045 .711 .709 \\
\hline \multicolumn{2}{|l|}{ Rata } & 690.443 .132 .507 & 327.731 .152 .778 & 1.018 .174 .285 .285 \\
\hline
\end{tabular}

Sumber: KPP Pratama Mataram Barat

Berdasarkan pada tabel 4.5 dapat dikatakan bahwa:

- Pada tahun 2015, jumlah wajib pajak orang pribadi dan badan sebanyak 93.272 orang. Penerimaan PPh sebesar Rp 536,606,425,330. Penerimaan PPN dan PPnBM sebesar Rp 273,161,678,332. Jadi, total penerimaan PPh, PPn dan PPnBM tahun 2015 sebesar Rp 809,768,103,662.

- Pada tahun 2016, jumlah wajib pajak orang pribadi dan badan sebanyak 99.283 orang. Penerimaan PPh sebesar Rp 683,586,604,237. Penerimaan PPN dan PPnBM sebesar Rp 314,141,019,679. Jadi, total penerimaan PPh, PPN dan PPnBM tahun 2016 sebesar Rp 997,727,623,952.

- Pada tahun 2017, jumlah wajib pajak orang pribadi dan badan sebanyak 104.523 orang. Penerimaan PPh sebesar Rp 733,276,916,251. Penerimaan PPN dan PPnBM sebesar Rp 348,829,567,307. Jadi total penerimaan PPh, PPN dan PPnBM tahun 2017 sebesar Rp 1,082,106,483,558.

- Pada tahun 2018, jumlah wajib pajak orang pribadi dan badan sebanyak 110.282 orang. Penerimaan PPh sebesar Rp 761,600,894,107. Penerimaan PPN dan PPnBM sebesar Rp 341,275,800,026. Jadi, total penerimaan PPh, PPN dan PPnBM tahun 2018 sebesar Rp 1,102,876,694,133.

- Pada tahun 2019, jumlah wajib pajak orang pribadi dan badan sebanyak 115.718 orang. Penerimaan PPh sebesar Rp 679,803,788,133. Penerimaan PPN dan PPnBM sebesar Rp 343,418,217,117. Jadi, total penerimaan PPh, PPN dan PPnBM tahun 2019 sebesar Rp 1,023,222,005,250.

- Pada tahun 2020, jumlah wajib pajak orang pribadi dan badan sebanyak 127.289 orang. Penerimaan PPh sebesar Rp 747,784,166,946. Penerimaan PPN dan PPnBM sebesar Rp 345,560,634,208. Jadi, total penerimaan PPh, PPN dan PPnBM tahun 2020 sebesar Rp 1,093,344,801,154.

Pertumbuhan Wajib Pajak Orang Pribadi dan Badan tiap tahunnya meningkat, begitu juga dengan Penerimaan PPh, PPN dan PPnBM meningkat karena pertumbuhan wajib pajak memiliki hubungan yang positif terhadap penerimaan pajak, maka dari itu 
naik turunnya penerimaan tergantung dari kepatuhan wajib pajak dan pertumbuhan wajib pajaknya.

Jumlah penerimaan PPh orang pribadi dan badan dari tahun 2015-2020 sebesar Rp 4,142,658,795,040 dengan rata-rata sebesar Rp 690,443,132,507. Sedangkan, jumlah penerimaan PPN dan PPnBM orang pribadi dan badan sebesar Rp $1,966,386,916,669$ dengan rata-rata sebesar Rp 327,731,152,778. Sehingga total penerimaan PPh, PPN dan PPnBM orang pribadi dan badan adalah Rp $6,109,045,711,709$ dengan total rata-rata Rp 1,018,174,285,285.

Total penerimaan tertinggi yaitu pada tahun 2020 dengan nilai sebesar Rp $1,093,344,801,154$. Pada tahun 2015, total penerimaan menurun dengan nilai sebesar Rp $809,768,103,662$. Jumlah wajib pajak tertinggi yaitu pada tahun 2020 sebanyak 127.289 orang. Jumlah wajib pajak terendah yaitu pada tahun 2015 sebanyak 93.272 orang.

Rumus yang digunakan untuk menghitung penerimaan adalah

Penerimaan $=\frac{\left(\mathrm{Pn}^{\left.-\mathrm{Pn}_{-1}\right)}\right.}{\mathrm{Pn}_{-1}} \times 100 \%$

Contoh:

\section{Pertumbuhan Wajib Pajak OP dan Badan}

Tahun $(2016-2015) / 2015 \times 100 \%$

$=(\underline{99283-93272}) \times 100$

$=6,44 \%$ 93272

Penerimaan PPh (Wajib Pajak OP dan Badan)

Tahun $(2016-2015) / 2015 \times 100 \%$

$=(\underline{683.586 .604 .237-536.606 .425 .330)} \times 100 \%$

536.606 .425 .330

$=27,39 \%$

Penerimaan PPN dan PPnBM (Wajib Pajak OP dan Badan)

Tahun (2016-2015)/2015 × 100\%

$=(314.141 .019 .679-273.161 .678 .332) \times 100 \%$

273.161.678.332

$=15,00 \%$

Total penerimaan PPh, PPN dan PPnBM (Wajib Pajak OP dan Badan)

Tahun $(2016-2015) / 2015 \times 100 \%$

$=\frac{(997.727 .623 .952-809.768 .103 .662)}{80100 \%}$

$=23,21 \%$

809.768.103.662

Pertumbuhan Penerimaan Pajak

Tabel 5. Pertumbuhan Penerimaan Pajak

\begin{tabular}{|c|c|c|c|c|}
\hline \multirow[b]{2}{*}{ Tahun } & \multirow{2}{*}{$\begin{array}{c}\text { Pertumbuhan } \\
\text { Wajib Pajak } \\
(\%)\end{array}$} & \multicolumn{2}{|c|}{ Pertumbuhan Penerimaan } & \multirow{2}{*}{$\begin{array}{c}\text { Total Pertumbuhan } \\
\text { Penerimaan } \\
(\%)\end{array}$} \\
\hline & & PPh (\%) & $\begin{array}{c}\text { PPN dan PPnBM } \\
(\%)\end{array}$ & \\
\hline 2015 & - & - & - & - \\
\hline 2016 & 6,44 & 27,39 & 15,00 & 23,21 \\
\hline 2017 & 5,28 & 7,27 & 11,04 & 8,46 \\
\hline 2018 & 5,51 & 3,86 & $-2,17$ & 1,92 \\
\hline 2019 & 4,93 & $-10,74$ & 0,63 & $-7,22$ \\
\hline 2020 & 10,00 & 10,00 & 0,62 & 6,85 \\
\hline JML & 32,16 & 37,78 & 25,13 & 33,22 \\
\hline Rata & 6,43 & 7,56 & 5,03 & 6,64 \\
\hline
\end{tabular}

Sumber: KPP Pratama Mataram Barat 
Berdasarkan tabel 4.6 dapat dikatakan bahwa:

\section{Pertumbuhan wajib pajak}

- Pada tahun 2015-2016 jumlah pertumbuhan wajib pajak sebanyak 6,44\% dari jumlah pertumbuhan wajib pajak pada tahun 2014.

- Pada tahun 2017, jumlah pertumbuhan wajib pajak sebanyak 5,28\%. Artinya pertumbuhan wajib pajak tahun 2017 cenderung menurun daripada pertumbuhan wajib pajak tahun 2016 dengan selisih 1,16\%.

- Pada tahun 2018, jumlah pertumbuhan wajib pajak sebanyak 5,51\%. Artinya pertumbuhan wajib pajak meningkat daripada pertumbuhan wajib pajak tahun 2017 sebanyak $0,23 \%$.

- Pada tahun 2019, jumlah pertumbuhan wajib pajak sebanyak 4,93\%. Artinya pertumbuhan wajib pajak tahun 2019 cenderung menurun daripada pertumbuhan wajib pajak tahun 2018 dengan selisih 0,58\%.

- Pada tahun 2020, jumlah pertumbuhan wajib pajak sebanyak $10,00 \%$. Artinya pertumbuhan wajib pajak tahun 2020 meningkat drastis daripada pertumbuhan wajib pajak tahun 2019 sebanyak 5,07\%.

Jadi jumlah pertumbuhan wajib pajak dari tahun 2015-2020 sebanyak

$32,16 \%$ dengan rata-rata $6,43 \%$.

\section{PPh, PPN dan PPnBM}

> Pada tahun 2016, jumlah pertumbuhan penerimaan PPh sebesar 27,39\%. Jumlah pertumbuhan penerimaan PPN dan PPnBM sebesar 15,00. Jadi total pertumbuhan penerimaan PPh, PPN dan PPnBM pada tahun 2016 sebesar 23,21\%.

$>$ Pada tahun 2017, jumlah pertumbuhan penerimaan PPh sebesar 7,27\%. Jumlah pertumbuhan penerimaan PPN dan PPnBM sebesar 11,04 . Jadi, total pertumbuhan penerimaan PPh, PPN dan PPnBM pada tahun 2017 sebesar 8,46\%.

$>$ Pada tahun 2018, jumlah pertumbuhan penerimaan PPh sebesar 3,86\%. Jumlah pertumbuhan penerimaan PPN dan PPnBM sebesar $-2,17$. Jadi total pertumbuhan penerimaan PPh, PPN dan PPnBM sebesar 1,92\%.

$>$ Pada tahun 2019, jumlah pertumbuhan penerimaan PPh sebesar $-10,74 \%$. Jumlah pertumbuhan penerimaan PPN dan PPnBM sebesar 0,63\%. Jadi total pertumbuhan penerimaan PPh, PPN dan PPnBM sebesar $-7,22 \%$.

$>$ Pada tahun 2020, jumlah pertumbuhan penerimaan PPh sebesar 10,00\%. Jumlah pertumbuhan penerimaan PPN dan PPnBM sebesar 0,62\%. Jadi total pertumbuhan penerimaan PPh, PPN dan PPnBM sebesar 6,85\%.

Jumlah pertumbuhan penerimaan PPh dari tahun 2015-2020 sebesar 37,78\% dengan rata-rata sebesar $7,56 \%$. Sedangkan, jumlah pertumbuhan penerimaan PPN dan PPnBM sebesar $25,13 \%$ dengan rata-rata sebesar 5,03\%. Sehingga total pertumbuhan penerimaan PPh, PPN dan PPnBM adalah 33,22\% dengan total rata-rata $6,64 \%$.

Jumlah wajib pajak tertinggi yaitu pada tahun 2020 sebanyak 10,00\% orang. Jumlah wajib pajak terendah yaitu pada tahun 2019 sebanyak 4,93\% orang. Total pertumbuhan penerimaan tertinggi yaitu pada tahun 2016 dengan nilai sebesar $23,21 \%$. Pada tahun 2018, total pertumbuhan penerimaan menurun dengan nilai sebesar $1,92 \%$.

Total pertumbuhan penerimaan dari tahun 2015-2020 kadang mengalami kenaikan kadang juga menurun. Pada tahun 2016 total pertumbuhan penerimaan mengalami kenaikan yaitu dengan total sebesar 23,21\%. Pada tahun 2017 total pertumbuhan penerimaan mengalami penurunan yaitu dengan total sebesar $8,46 \%$. Pada tahun 2018 total pertumbuhan penerimaan mengalami penurunan yang sangat drastis dengan total sebesar 1,92\%. Pada tahun 2019 total pertumbuhan penerimaan 
mengalami kenaikan yaitu dengan total sebesar $-7,22 \%$. Dan pada tahun 2020 total pertumbuhan penerimaan mengalami penurunan yaitu dengan total sebesar $6,85 \%$.

Rumus yang digunakan untuk menghitung pertumbuhan penerimaan adalah

Pertumbuhan Penerimaan

$$
=\frac{\sum \text { Penerimaan thn ini }-\sum \text { Penerimaan thn sebelumnya }}{\sum \text { Penerimaan thn sebelumnya }}
$$

\section{Contoh:}
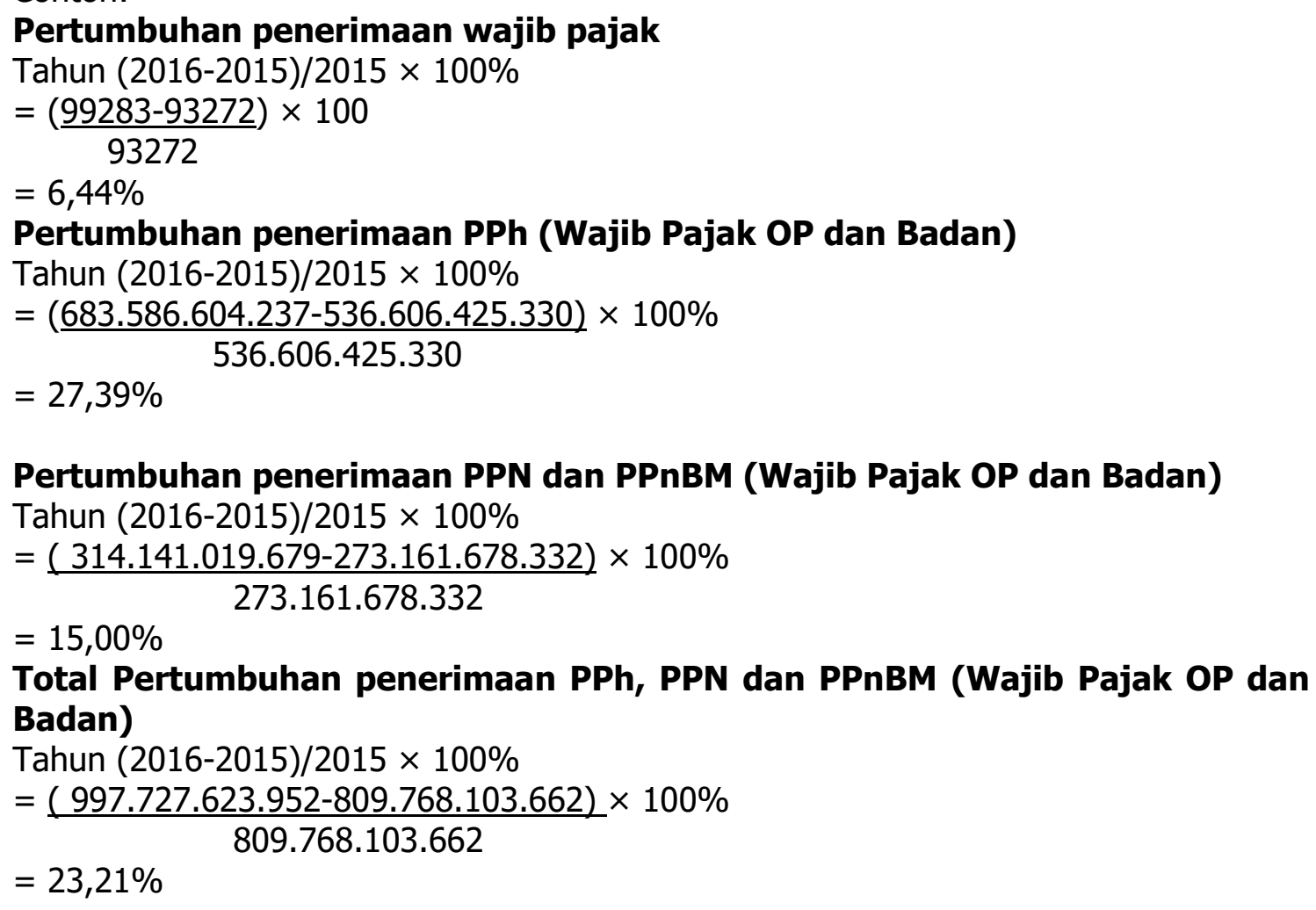

Dari penjelasan tabel 4.3 (Wajib Pajak Orang Pribadi) menunjukkan bahwa wajib pajak orang pribadi dari tahun 2015-2020 meningkat begitu juga dengan perkembangan wajib pajaknya meningkat dari tahun ke tahun. Sedangkan pada tabel 4.4 (wajib pajak badan) menunjukkan bahwa wajib pajak badan dari tahun 2015-2020 meningkat akan tetapi perkembangan wajib pajaknya tidak menentu kadang mengalami kenaikan kadang menurun. Sedangkan pada tabel 4.4 dan 4.5 pertumbuhan wajib pajak dan penerimaan pajak (PPh, PPN dan PPnBM) dari tahun ke tahun meningkat.

Peningkatan jumlah Wajib Pajak dan Penerimaan Pajak (PPh, PPN dan PPnBM) meningkat atau menurun dipengaruhi oleh kepatuhan Wajib Pajak dalam melaporkan pajak yang menjadi kewajibannya kepada Negara. Kepatuhan Wajib Pajak mempunyai hubungan positif dengan Pertumbuhan Wajib Pajak dan Penerimaan Pajak. Apabila Wajib Pajak patuh membayar pajak maka pertumbuhan Wajib Pajak akan meningkat begitu juga dengan penerimaan pajak. Pada tabel diatas terlihat jelas bahwa ada hubungan yang sangat erat antara pertumbuhan wajib pajak dan penerimaan pajak di KPP Pratama Mataram Barat. Jika penambahan Wajib Pajak setiap tahunnya meningkat ataupun menurun dapat mendorong kenaikan atau peningkatan penerimaan pajak. 
Peningkatan jumlah Wajib Pajak sangat mendukung penerimaan pajak penghasilan di KPP Pratama Mataram Barat. Terbukti dari tabel diatas bahwa hubungan antara pertumbuhan wajib pajak dengan penerimaan pajak dinyatakan sangat kuat, hubungan ini menunjukkan bahwa semakin besar jumlah pertumbuhan wajib pajak, maka semakin besar jumlah penerimaan pajak (PPh, PPN dan PPnBM) seperti yang tertera pada tabel diatas.

\section{SIMPULAN}

Berdasarkan pembahasan laporan Hubungan antara Pertumbuhan Wajib Pajak dan Penerimaan Pajak di KPP Pratama Mataram Barat dapat disimpulkan sebagai berikut: Jumlah Wajib Pajak Orang Pribadi dan jumlah perkembangan Wajib Pajak meningkat dari tahun ke tahun yaitu 2015-2020, Jumlah Wajib Pajak Badan dari tahun ke tahun meningkat akan tetapi jumlah Perkembangan Wajib Pajak bertlukuratif, Pertumbuhan Penerimaan Wajib pajak OP dan Badan tiap tahunnya bertlukuratif begitu juga dengan Pertumbuhan Penerimaan PPh, PPN, dan PPnBM Wajib pajak OP dan Badan dan total Pertumbuhan Penerimaannya tiap tahunnya bertlukuratif, Pertumbuhan Wajib Pajak Orang Pribadi dan Badan tiap tahunnya meningkat, begitu juga dengan Penerimaan PPh, PPN dan PPnBM tiap tahunnya meningkat karena pertumbuhan wajib pajak memiliki hubungan yang positif terhadap penerimaan pajak, maka dari itu naik turunnya penerimaan tergantung dari kepatuhan Wajib Pajak dan Pertumbuhan Wajib Pajaknya, Kepatuhan wajib pajak mempunyai hubungan positif dengan penerimaan pajak. Apabila wajib pajak patuh membayar pajak maka pertumbuhan penerimaan pajak akan meningkat dan Jika penambahan wajib pajak setiap tahunnya meningkat ataupun menurun dapat mendorong kenaikan atau peningkatan penerimaan pajak. Peningkatan jumlah wajib pajak sangat mendukung penerimaan pajak penghasilan di KPP Pratama Mataram Barat.

\section{DAFTAR PUSTAKA}

Anonim, 2021, "Buku Pedoman Praktek Kerja Lapangan (PKL)', 2021, Program Diploma III Perpajakan Fakultas Ekonomi Dan Bisnis Universitas Mataram.

Anonim,_ https://ejournal.unsri.ac.id/index.php/ja/article/download/10716/5608. (diakses pada tanggal 8 maret 2021)

Anonim, Penerimaan Pajak dan Pertumbuhan Wajib Pajak dikutip dari online http://repository.um-palembang.ac.id $>\ldots$ (diakses pada tanggal 8 maret 2021)

Mardiasmo, MBA.,Ak, 2011," Perpajakan "edisi revisi 2011 Andi. Yogyakarta.

Mardiasmo. 2016. "Perpajakan" edisi revisi 2016 Andi. Yogyakarta.

Waluyo, 2011, " Perpajakan Indonesia "edisi 2011, SALEMBA EMPAT, Jakarta 